\title{
Impact of Livestock Exclusion on Sidi Toui National Park Vegetation Communities, Tunisia
}

\author{
Mohamed Tarhouni, Farah Ben Salem, \\ Azaiez Ouled Belgacem, and Mohamed Neffati
}

\author{
Institut des Régions Arides, Laboratoire d'Ecologie Pastorale, 4119 Médenine, Tunisia \\ Correspondence should be addressed to Mohamed Tarhouni; medhtarhouni@yahoo.fr
}

Received 4 February 2014; Accepted 16 April 2014; Published 12 May 2014

Academic Editor: Anita Diaz

Copyright (c) 2014 Mohamed Tarhouni et al. This is an open access article distributed under the Creative Commons Attribution License, which permits unrestricted use, distribution, and reproduction in any medium, provided the original work is properly cited.

\begin{abstract}
The restoration technique importance resides on the assessment of its impact on biodiversity. This assessment is possible by the use of some environmental indicators extracted from a diachronic study of land cover changes in protected areas. Our study is carried out with the evaluation of some indicators inside Sidi Toui national park. These indicators are measured on the one hand from a land cover map of 1988 ( 3 years before the creation of the park) and the map of 2007 on the other hand (16 years after the park creation). An important landscape heterogeneity, as a result of the progressive vegetation dynamic, was observed in 2007 . This heterogeneity is indicated by an increasing of the Shannon diversity index under fencing impacts. The majority of 1988 vegetation units are replaced by new ones in 2007. The cover of all vegetation units is more important in 2007.
\end{abstract}

\section{Introduction}

It is considered that the Mediterranean region, subjected to pronounced climatic and edaphic droughts, does not contain any unaltered terrestrial ecosystems [1-3]. In Presaharian Tunisia, defined by Floret and Pontanier [4] as the zone located between the isohyets 100 and $200 \mathrm{~mm}$, the consequences of desertification became progressively a major environmental problem during the last decades [5]. In this zone the natural vegetation cover, mainly composed by very sparse steppic vegetation units, is altered by various human activities [6,7]. Usually these activities lead to overgrazing after losing rangeland area (cultivation and ploughing impact) and increasing the number of animals (mainly sheep and goats).

In order to protect natural vegetation units and limit their degradation, it should be necessary to decrease the human impact and enhance the ecosystems regeneration. This last can be carried out with protection, reducing grazing pressure and soil fertility improvement $[8,9]$. Otherwise, it is necessary to identify and to use a lot of ecological indicators [10] in order to facilitate the vegetation dynamic monitoring.
The environmental monitoring indicators can be considered like a particular case of indicators ([11] (OSS: Observatoire du Sahara et du Sahel (Sahara and Sahel Observatory); ROSELT: Réseau d'Observatoires de Surveillance Écologique à Long-Terme (Long-Term Ecological Monitoring Observatories Network))). They permit, on the basis of data collected from the observation sites, the invention of structural elements describing and valuing the environmental status. These indicators are considered like an adapted tool for the natural resource managers and policies makers. Environmental monitoring indicators can (i) be considered like the basis of information for making decision, (ii) help the internal and/or external assessment function (case of the social indicators), and (iii) constitute elements of common world or good collective definitions and means to reach them. In this context our study is integrated. Its main objective is to evaluate the land cover dynamics in Sidi Toui national park using a lot of environmental monitoring indicators. It is necessary to determine whether exclusion of grazing has led to vegetation dynamic indicated by physiognomic changes, vegetation cover differences, and habitats diversity tendency inside the park. 


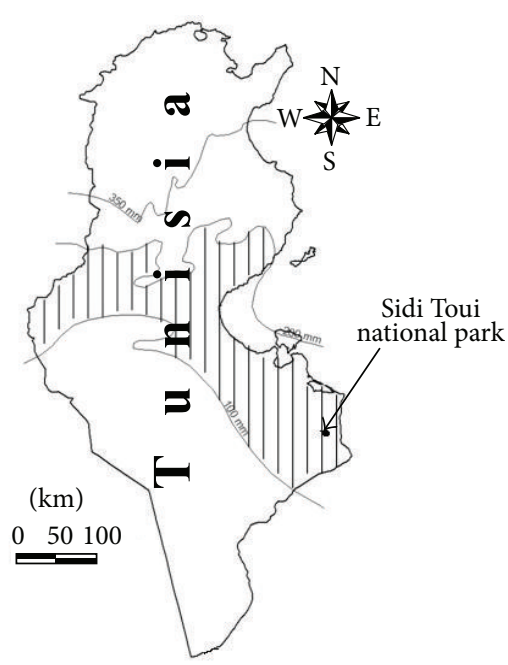

Figure 1: Geographic location of Sidi Toui national park on Presaharian Tunisia (hatched part).

\section{Materials and Methods}

2.1. Study Site. Sidi Toui national park (created in 1991, 6315 ha) is located in Presaharian Tunisia (Figure 1). Its soil substratum is mainly composed of vast encrusted glacis with sandy and thin top layer. The vegetation cover is mainly dominated by chamaephytes.

The annual rainfall recorded in the park during the period from 1991 to 2008 is done in Figure 2. Seven years of 17 are dry. The humid and very humid years are exceptional. The period from 2003 to 2008 is characterised by an important interannual variability of rain which can be probably explained by the effects of current global climatic changes. The rain efficiency in the park is more than $10 \mathrm{~mm}$. The lowest $(<10 \mathrm{~mm})$ and unpredictable rainfall, which quickly evaporated, cannot allow the spontaneous plant regeneration. However, plant species can appropriately survive when annual rainfall exceeds $250 \mathrm{~mm}$ [12].

2.2. Methods. The study of land cover dynamic inside Sidi Toui national park is made with the superposition and the comparison of two maps using GIS Arcview 3.2 software (Figure 3). The first one was performed by Moussa and Zaâfouri [13] using aerial photographs (date 1967; scale $1 / 25000$ ). This map reflects the situation of land cover 3 years before the park creation. The second map, elaborated by Tarhouni [14], represents the situation of land cover 16 years after the park creation. This map is carried out using a Landsat satellite image (date Marsh 2000) and Braun-Blanquet vegetation relevés during the spring of 2007 [15]. This image is visually interpreted in order to limit the same colour polygon. The vegetation relevés, measuring plant species abundance, are statically manipulated (presence/absence and abundance/dominance factorial correspondence analysis) in order to identify the different vegetation units inside the park.
In order to assess the main land cover trends we use a lot of environmental monitoring indicators [11]:

(i) physiognomic change: descriptive parameter based on spatiotemporal changes of vegetation units; it can be evaluated following qualitative (vegetation physiognomy) or quantitative criteria (changing area ...);

(ii) changes in global vegetation cover: it is the vertical projection on the ground of the aerial part of plant species [16];

(iii) habitat diversity: described by the Shannon diversity indexes; it assesses the vegetation units diversity which corresponds to the landscape heterogeneity. The vegetation units diversity is calculated as

$$
H^{\prime}=-\sum_{i=1}^{S} p_{i}\left(\log _{2} p_{i}\right)
$$

with $p_{i}=$ area of the unit $i$ /area of the park; $S$ is the number of vegetation units.

The habitats diversity can also be calculated using several indexes like the following.

(i) Regularity $(R)$ : in order to compare populations with different specific richness the regularity index was used:

$$
R=\frac{H^{\prime}}{H_{\max }}
$$

with $H_{\max }=\log _{2} S$; $S$ is the number of vegetation units.

(ii) Simpson index: this index varies from 0 to 1 for indicating the maximum and the minimum of diversity, respectively. As known this diversity index gives more weight to the abundant species than to the rare one:

$$
D=\sum_{i=1}^{S} p_{i}^{2}
$$

with $p_{i}=$ area of the unit $i /$ area of the park.

(iii) Hill index: it allows the precision of the observed diversity:

$$
\text { Hill }=\frac{(1 / D)}{e^{H^{\prime}}},
$$

where $1 / D$ is the inverse of Simpson's index and $e^{H^{\prime}}$ is the exponential of Shannon index.

The vegetation units evolution is evaluated by the change in the area of each unit as

$$
\text { Change }=\left(\text { Area }_{2008}-\text { Area }_{1988}\right) * \frac{100}{\text { Area }_{1988}} .
$$




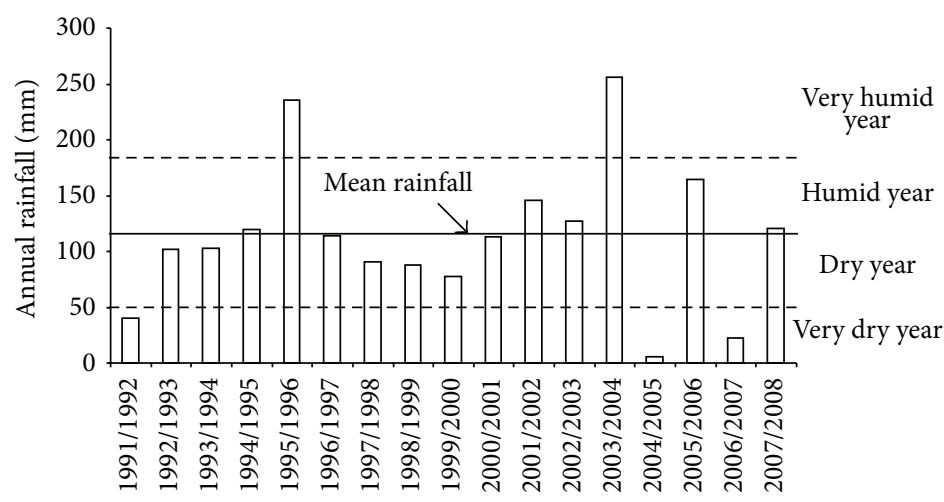

Figure 2: Annual rainfall (mm) recorded in Sidi Toui national park from 1991 to 2008. The mean rainfall is calculated from the 17-year data; the dotted lines are mean \pm SD.

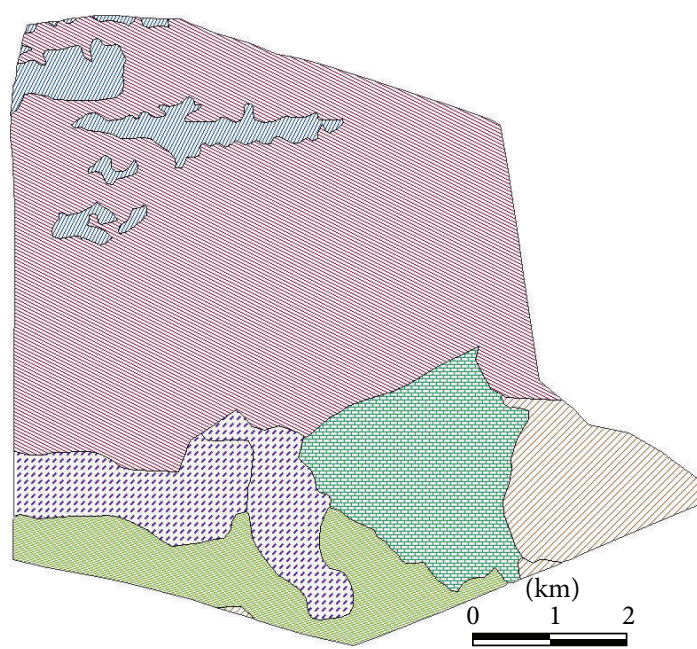

Land cover map of the year 1988

Anthyllis henoniana and Gymnocarpos decander Haloxylon schmittianum

Haloxylon schmittianum and Gymnocarpos decander

Rhanterium suaveolens and Haloxylon schmittianum

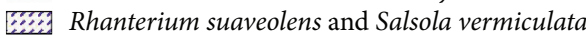

Stipagrostis pungens

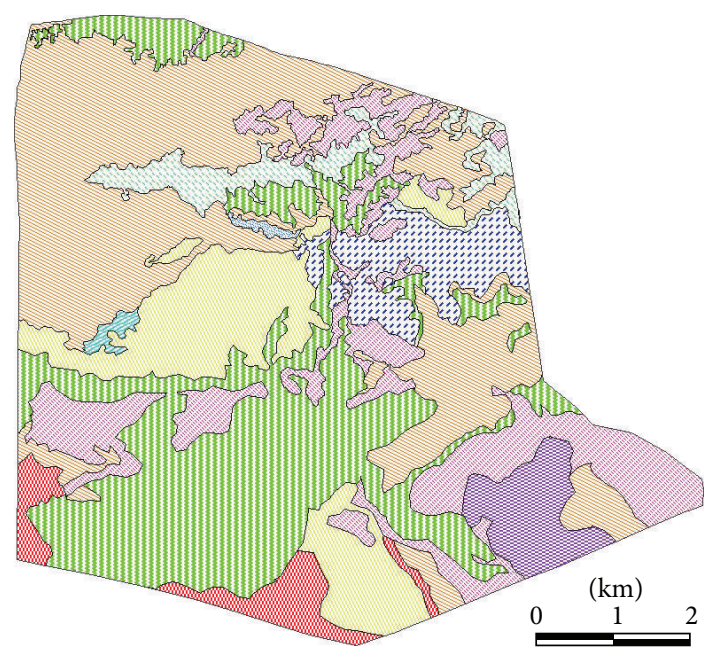

Land cover map of the year 2007

Anthyllis henoniana and Gymnocarpos decander

Haloxylon schmittianum and Haloxylon scoparium

Helianthemum kahiricum and Anthyllis henoniana

Retama raetam and Stipagrostis pungens

餎 Stipa lagascae

Stipagrostis pungens

Cenchrus ciliaris

[:;:- Periploca angustifolia and Ziziphus lotus

[IIII Rhanterium suaveolens and Helianthemum kahiricum

厲哭 Rhanterium suaveolens and Stipa lagascae

FIGURE 3: Land cover maps of the years 1988 [13] and 2007 [14] inside Sidi Toui national park.

\section{Results}

Table 1 shows the physiognomic changes of vegetation units inside Sidi Toui national park from 1988 to 2007. The number of vegetation unit increases from 6 to 13 during this period. It seems that their composition becomes different and their heterogeneity is more remarkable. All 1988 vegetation units are negatively advanced in 2007 when many new units appear. These last are due to the progressive vegetation dynamic.

The quantitative analysis of the physiognomic changes inside Sidi Toui national park during the period from 1988 to 2007 is given in Table 2. It seems that all 1988 vegetation units are replaced by many new units in 2007. The number of the new vegetation units is important when the original unit is big.

Figure 4 shows an important habitat diversity after 16 years of fencing inside Sidi Toui national park. The Shannon diversity indexes $\left(H^{\prime}\right.$ and $\left.H_{\max }\right)$ increase between 1988 and 2007 indicating more obvious landscape heterogeneity. This same result is done by the Simpson index $(D)$ which decreases during the studied period showing an increase of habitats diversity. In contrast the regularity $(R)$ and the Hill indexes do not give a clear tendency.

The global vegetation cover variation of all units is done in Table 3. All vegetation unit covers are more important in 
TABle 1: Physiognomic changes inside Sidi Toui national park between 1988 and 2007.

\begin{tabular}{|c|c|c|}
\hline & 1988 & 2007 \\
\hline Number of vegetation units & 6 & 13 \\
\hline$\%$ of area of $A$. henoniana \& $G$. decander unit & 57.25 & 30.72 \\
\hline$\%$ of area of $H$. schmittianum unit & 11.16 & - \\
\hline$\%$ of area of R. suaveolens \& S. vermiculata unit & 9.81 & - \\
\hline$\%$ of area of $R$. suaveolens \& H. schmittianum unit & 9.53 & 0.02 \\
\hline$\%$ of area of $H$. schmittianum \& G. decander unit & 7.26 & 0.01 \\
\hline$\%$ of area of $S$. pungens unit & 4.98 & 0.38 \\
\hline \multirow{4}{*}{ Evolution of vegetation units between 1988 and 2007} & A. henoniana \& G. decander & -46 \\
\hline & R. suaveolens \& H. schmittianum & -100 \\
\hline & H. schmittianum \& G. decander & -100 \\
\hline & S. pungens & -92 \\
\hline \multirow{6}{*}{ Number of substitution units } & A. henoniana \& G. decander & 8 units \\
\hline & H. schmittianum & 6 units \\
\hline & R. suaveolens \& S. vermiculata & 5 units \\
\hline & R. suaveolens \& H. schmittianum & 5 units \\
\hline & H. schmittianum \& G. decander & 5 units \\
\hline & S. pungens & 3 units \\
\hline
\end{tabular}

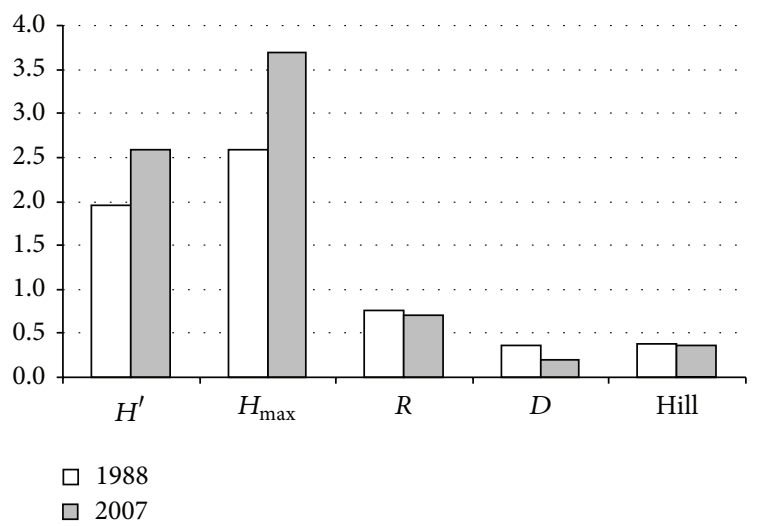

FIGURE 4: Habitat diversity indexes inside Sidi Toui national park between 1988 and 2007. $H^{\prime}$ and $H_{\max }$ are the Shannon indexes; $R, D$, and Hill are the regularity, Simpson, and Hill indexes, respectively.

2007. These covers are different between vegetation units. This variation can probably be explained by the difference between the soil characteristics and vegetation types. For example, on sandy substratum, vegetation dynamic as well as plant development is easier than the skeletal one.

\section{Discussion}

Since the beginning of the 20th century, Clements [17] used "succession" for describing the autogenic development of vegetation units until a "climax" state where vegetation can reach its equilibrium status with edaphoclimatic conditions. Succession is a natural process which determines consecutive changes in the floristic composition in response to different ecosystem changes [18]. It may be multidirectional because the vegetation units are usually resulting from unpredictable disasters series (prolonged drought, fire, etc.) [19]. The concepts of competition and interaction between plants and their environment were used in order to analyse changes in the floristic composition during succession [20, 21]. During these changes, called "changing environments," the first plant species facilitates the development of other plants which will eventually replace it [22]. Rainfall pattern affects all plant dynamic phases in dry areas. Interannual variations of precipitation can be considered as a major factor of plant development and diversity levels. In fact, during humid year, many plants (especially annuals) are observed and plant diversity increases, but, in dry year, only perennials survive and the diversity is lower.

Grazing activity is the main land use before the park creation. Animals deteriorate the natural vegetation cover and lead to the plant communities' homogeneity [23]. Under grazing, the vegetation cover is composed by few and degraded perennial plants, annuals are more abundant during the rainy period, and the soil substratum is eroded. However, the absence of animals in protected areas enhances perennial development, the soil particles are fixed, and annual plants can appropriately survive. These last contribute to the soil fertility and encourage the development of some other plant species. This is not general for all vegetation units because many plant species tolerate degradation and progressively disappeared when protected. For example, Stipagrostis pungens tolerates sand movement [24], but it cannot tolerate heavy disturbances such as grazing and trampling [25]. The rarefaction of this species is still remarkable after soil fixation and other plants begin their development and replace it (Table 2). This vegetation dynamic facilitates the installation of many new units and increases their heterogeneity. 
TABLE 2: Quantitative analysis of physiognomic changes of vegetation units inside Sidi Toui national park between 1988 and $2007 . \%$ initial indicates the percentage of the current unit from the original one and the $\%$ total indicates the percentage of the current unit from the total area of the park.

\begin{tabular}{|c|c|c|c|c|c|}
\hline \multicolumn{2}{|l|}{ Year 1988} & \multicolumn{2}{|l|}{ Year 2007} & \multirow{2}{*}{$\%$ initial } & \multirow{2}{*}{$\%$ total } \\
\hline Original steppe & Area (ha) & Current steppe & Area (ha) & & \\
\hline \multirow{9}{*}{ A. henoniana \& G. decander } & \multirow{9}{*}{3712.90} & A. henoniana \& G. decander & 1402.07 & 37.76 & 21.61 \\
\hline & & R. suaveolens \& H. kahiricum & 663.46 & 17.87 & 10.23 \\
\hline & & H. schmittianum \& H. scoparium & 527.25 & 14.20 & 8.13 \\
\hline & & H. kahiricum \& A. henoniana & 501.19 & 13.50 & 7.73 \\
\hline & & P. angustifolia \& Z. lotus & 332.33 & 8.95 & 5.12 \\
\hline & & R. raetam \& S. pungens & 248.10 & 6.68 & 3.82 \\
\hline & & S. pungens & 24.11 & 0.65 & 0.37 \\
\hline & & C. ciliaris & 14.30 & 0.39 & 0.22 \\
\hline & & R. suaveolens \& S. lagascae & 0.08 & $<0.01$ & $<0.01$ \\
\hline \multirow{6}{*}{ H. schmittianum } & \multirow{6}{*}{723.76} & R. suaveolens \& H. kahiricum & 272.63 & 37.67 & 4.20 \\
\hline & & A. henoniana \& G. decander & 183.45 & 25.35 & 2.83 \\
\hline & & H. kahiricum \& A. henoniana & 181.74 & 25.11 & 2.80 \\
\hline & & S. lagascae & 68.78 & 9.50 & 1.06 \\
\hline & & H. schmittianum \& H. scoparium & 16.00 & 2.21 & 0.25 \\
\hline & & R. suaveolens \& S. lagascae & 1.15 & 0.16 & 0.02 \\
\hline \multirow{6}{*}{ R. suaveolens \& S. vermiculata } & \multirow{6}{*}{636.40} & R. suaveolens \& H. kahiricum & 443.25 & 69.65 & 6.83 \\
\hline & & R. suaveolens \& S. lagascae & 73.53 & 11.55 & 1.13 \\
\hline & & H. schmittianum \& H. scoparium & 58.05 & 9.12 & 0.89 \\
\hline & & A. henoniana \& G. decander & 34.08 & 5.35 & 0.53 \\
\hline & & H. kahiricum \& A. henoniana & 27.48 & 4.32 & 0.42 \\
\hline & & R. suaveolens \& S. vermiculata & 0.01 & $<0.01$ & $<0.01$ \\
\hline \multirow{6}{*}{ R. suaveolens \& H. schmittianum } & \multirow{6}{*}{618.28} & R. suaveolens \& H. kahiricum & 275.71 & 44.59 & 4.25 \\
\hline & & H. schmittianum \& H. scoparium & 146.79 & 23.74 & 2.26 \\
\hline & & R. suaveolens \& S. lagascae & 139.02 & 22.48 & 2.14 \\
\hline & & H. kahiricum \& A. henoniana & 31.85 & 5.15 & 0.49 \\
\hline & & A. henoniana \& G. decander & 23.86 & 3.86 & 0.37 \\
\hline & & R. suaveolens \& H. schmittianum & 1.04 & 0.17 & 0.02 \\
\hline \multirow{6}{*}{ H. schmittianum \& G. decander } & \multirow{6}{*}{471.02} & H. kahiricum \& A. henoniana & 211.53 & 44.91 & 3.26 \\
\hline & & S. lagascae & 164.36 & 34.89 & 2.53 \\
\hline & & A. henoniana \& G. decander & 77.47 & 16.45 & 1.19 \\
\hline & & R. suaveolens \& H. kahiricum & 13.19 & 2.80 & 0.20 \\
\hline & & R. suaveolens \& S. lagascae & 3.76 & 0.80 & 0.06 \\
\hline & & H. schmittianum \& G. decander & 0.71 & 0.15 & 0.01 \\
\hline \multirow{5}{*}{ S. pungens } & \multirow{5}{*}{322.82} & A. henoniana \& G. decander & 271.64 & 84.15 & 4.19 \\
\hline & & H. kahiricum \& A. henoniana & 29.02 & 8.99 & 0.45 \\
\hline & & R. raetam \& S. pungens & 11.29 & 3.50 & 0.17 \\
\hline & & R. suaveolens \& H. kahiricum & 10.55 & 3.27 & 0.16 \\
\hline & & S. pungens & 0.33 & 0.10 & 0.01 \\
\hline
\end{tabular}

Under harsh environmental conditions, the change of plant species is high during the first decade after disturbance [26]. For example, the number of plant species (annual and perennial) increases with the succession process until 18 years of fencing when the number of annual declines [27]. Equally the structure, composition, and life form of plant species will change [28]. The long fencing uncrushed the soil surface and decreased seed emergency and plant growth. Hence the regeneration of vegetation units decreased and the succession process slows.

It has been shown that disturbance changes the vegetation composition and structure $[14,29]$. Several works $[14,23,30]$ 
TABLE 3: Vegetation cover variation (in \%) inside Sidi Toui national park at 1988 and 2007.

\begin{tabular}{lcc}
\hline Vegetation units & Year 1988 & Year 2007 \\
\hline A. henoniana \& G. decander & $7.5 \pm 2.5$ & $12.5 \pm 2.5$ \\
C. ciliaris & - & $12.5 \pm 2.5$ \\
H. kahiricum \& A. henoniana & - & $12.5 \pm 2.5$ \\
H. schmittianum & $7.5 \pm 2.5$ & - \\
H. schmittianum \& G. decander & $2.5 \pm 2.5$ & $12.5 \pm 2.5$ \\
H. schmittianum \& H. scoparium & - & $12.5 \pm 2.5$ \\
P. angustifolia \& Z. lotus & - & $17.5 \pm 2.5$ \\
R. raetam \& S. pungens & - & $7.5 \pm 2.5$ \\
R. suaveolens \& H. kahiricum & - & $12.5 \pm 2.5$ \\
R. suaveolens \& H. schmittianum & $7.5 \pm 2.5$ & $17.5 \pm 2.5$ \\
R. suaveolens \& S. lagascae & - & $17.5 \pm 2.5$ \\
R. suaveolens \& S. vermiculata & $10 \pm 0.5$ & $12.5 \pm 2.5$ \\
S. lagascae & - & $17.5 \pm 2.5$ \\
S. pungens & $7.5 \pm 2.5$ & $7.5 \pm 2.5$ \\
\hline
\end{tabular}

showed that vegetation diversity is mainly influenced by the disturbance degree. Grazing activities lead to the dominance of unpalatable plant species instead of the palatable one [31]. However some plant species can tolerate the controlled grazing which reduces their aerial parts and allows their root system to support their water needs [32].

The autogenic restoration regenerates vegetation cover which reduces the effects of heat and drought stress on the soil surface, fixes the soil particle, enhances the ecosystem dynamic, and increases the landscape heterogeneity $[28,33$, 34]. The beneficial effect of fencing on spatial heterogeneity was highlighted by several authors $[9,14]$. From 3 to 6 years and up to 10 years of protection, Zhang et al. [27] showed an increase of the Shannon diversity index $\left(H^{\prime}\right)$. However this index decreases sharply from 10 to 18 years of fencing. Our study shows an important spatial heterogeneity after 16 years of protection. This diversity is indicated by an increase of the Shannon index and a decrease of the Simpson one. However the Hill and the regularity indexes do not show a clear tendency depending on the increase or the decrease of landscape diversity. These last are more suitable for the comparison of species diversity (intraspecific diversity) and give less information on the ecosystem/landscape (interspecific) diversity.

In future work it will be necessary to study the effect of harsh climatic conditions on the plant development inside the park using synchronic methods. The effect of the soil substratum on plant regeneration should be studied in order to understand the future evolution of plant communities inside the park.

\section{Conclusion}

In southern Tunisia the floristic cortege is subjected to several constraints dealing with the climate and soil conditions and human disturbance. The effects of these factors increase the risks of plant communities' degradation. In order to preserve this floristic heritage many management practices were used.
In this work we study the effect of restoration technique on plant regeneration inside Sidi Toui national park using long-term environmental monitoring indicators. The main results show a progressive plant dynamic resulting from the development of new vegetation units, an increase of the spatial heterogeneity, and vegetation cover. Such results help the natural resource managers and policies makers when evaluating the efficiency of the restoration impact on natural vegetation cover dynamic.

\section{Conflict of Interests}

The authors declare that there is no conflict of interests regarding the publication of this paper.

\section{References}

[1] J. Aronson, C. Floret, E. Le Floc'h, C. Ovalle, and R. Pontanier, "Restoration and rehabilitation of degraded ecosystems in arid and semi-arid lands. I. A view from the South," Restoration Ecology, vol. 1, no. 1, pp. 8-17, 1993.

[2] J. Aronson, C. Floret, E. Le Floc'h, C. Ovalle, and R. Pontanier, "Restoration and rehabilitation of degraded ecosystems in arid and semi-arid lands. I. A view from the South," Restoration Ecology, vol. 1, no. 3, pp. 168-187, 1993.

[3] F. Ramade, "Conservation des écosystèmes méditerranéens," in Les Fascicules du Plan Bleu, Economica, Paris, France, 1997.

[4] C. Floret and R. Pontanier, Laridité en Tunisie Présaharienne: Climat, Sol, Végétation et aménagement, vol. 150, ORSTOM, 1982.

[5] A. O. Belgacem and M. Neffati, "Etude de la dynamique de la végétation en milieu saharien," Revue des Régions Arides, pp. 252-257, 1996.

[6] C. Floret, E. Le Floc'h, and R. Pontanier, "Phytomasse et production végétale en Tunisie présaharienne," Acta Oecologica, vol. 4, no. 18, pp. 133-152, 1983.

[7] E. Le Floc'h, "Les écosystèmes des zones arides du Nord de l'Afrique: orientation pour l'établissement d'un réseau de réserves de biosphère," in Essai de Synthèse sur la Végétation et la Phyto-Écologie Tunisienne, M. A. Nabli, Ed., vol. 5 et 6 of Ouvrage Collectif sur le Milieu Physique et la Végétation, pp. 309-321, Faculté des Sciences de Tunis, Agence de Coopération Culturelle et Technique, MAB, Tunis, Tunisie, 1995.

[8] P. Martiniello, G. D’Agnano, O. Padalino, and F. Nardelli, "Effects of fertilisation on flora, biomass and seed production and soil fertility in four natural pastures of the Mediterranean basin," Options Mediterraneennes, vol. 12, pp. 87-90, 1995.

[9] M. Tarhouni, A. Ouled Belgacem, M. Neffati, and M. Chaieb, "Dynamique des groupements végétaux dans une aire protégée de Tunisie méridionale," Cahiers Agricultures, vol. 16, no. 1, pp. 23-29, 2007.

[10] OCDE, Indicateurs d'environnement, Organisation de Coopération et Développement Economiques, 1994.

[11] OSS/ROSELT, "Surveillance environnementale à long terme en réseau circum-saharien: synthèse Afrique du Nord 'FloreVégétation-Occupation des terres"' DRAFT, 2008.

[12] M. Chaieb, Influence des Réserves Hydriques du Sol sur le Comportement Comparé de Quelques Espèces Végétales de la Zone Aride Tunisienne, Lille University of Science and Technology, Montpellier, France, 1989. 
[13] M. Moussa and M. Zaâfouri, "Carte d'occupation des terres et des ressources pastorales d'el-Ouara, projet: TUN 86/002," Cartographie des Ressources Pastorales dans les Zones de Mise en Valeur de Sud, 1988.

[14] M. Tarhouni, Indicateurs de biodiversité et dynamique du couvert végétal naturel aux voisinages de trois points d'eau en zone aride tunisienne: cas des parcours collectifs del-Ouara [Ph.D. thesis], Faculte des Science de Tunis, 2008.

[15] J. Braun-Blanquet, in Premier Aperçu Phytosociologique du Sahara Tunisien, Travaux botaniques dédiés à René Maire, Societé d'Histoire Naturelle de l'Afrique du Nord, 1949.

[16] P. Daget and M. Godron, Pastoralisme: Troupeaux, Espèces et Sociétés, Hatier, Paris, France, 1995.

[17] F. E. Clements, Plant Succession: On Analysis of the Development of Vegetation, vol. 242, Carnegie Institution for Science, Washington, DC, USA, 1916.

[18] P. Roovers, B. Bossuyt, H. Gulinck, and M. Hermy, "Vegetation recovery on closed paths in temperate deciduous forests," Journal of Environmental Management, vol. 74, no. 3, pp. 273281, 2005.

[19] T. Telahigue, C. Floret, and E. Le Floc'h, "Post-cultivational succession in the arid zone of Tunisia," Acta Oecologica/Oecologia Plantarum, vol. 8, no. 1, pp. 45-58, 1987.

[20] J. M. Connell and R. O. Slatyer, "Mechanism of succession in natural communities and their role in community stability and organisation," The American Naturalist, vol. 111, pp. 1119-1144, 1977.

[21] E. P. Odum, “The strategy of ecosystem development," Science, vol. 164, no. 3877, pp. 262-270, 1969.

[22] C. Prado, Un modèle de succession végétale: rôle des traits biologiques des espèces et des contraintes spatiales [Ph.D. thesis], University of Paris VI, Paris, France, 1988.

[23] M. Tarhouni, A. O. Belgacem, M. Neffati, and B. Henchi, "Validation de quelques attributs structuraux de l'écosystème sous l'effet de la sécheresse saisonnière et la pression animale autour de points d'eau en zone aride tunisienne," Belgian Journal of Botany, vol. 139, no. 2, pp. 188-202, 2006.

[24] F. Bendali, C. Floret, E. Le Floc'h, and R. Pontanier, "The dynamics of vegetation and sand mobility in arid regions of Tunisia," Journal of Arid Environments, vol. 18, no. 1, pp. 21-32, 1990.

[25] M. Tarhouni, A. O. Belgacem, M. Neffati, and B. Henchi, "Qualification of rangeland degradation using plant life history strategies around watering points in southern Tunisia," Pakistan Journal of Biological Sciences, vol. 10, no. 8, pp. 1229-1235, 2007.

[26] A. Bonet, "Secondary succession of semi-arid Mediterranean old-fields in south-eastern Spain: insights for conservation and restoration of degraded lands," Journal of Arid Environments, vol. 56, no. 2, pp. 213-233, 2004.

[27] J. Zhang, H. Zhao, T. Zhang, X. Zhao, and S. Drake, "Community succession along a chronosequence of vegetation restoration on sand dunes in Horqin Sandy Land," Journal of Arid Environments, vol. 62, no. 4, pp. 555-566, 2005.

[28] J.-T. Zhang, "Succession analysis of plant communities in abandoned croplands in the eastern Loess Plateau of China," Journal of Arid Environments, vol. 63, no. 2, pp. 458-474, 2005.

[29] K. L. Metzger, M. B. Coughenour, R. M. Reich, and R. B. Boone, "Effects of seasonal grazing on plant species diversity and vegetation structure in a semi-arid ecosystem," Journal of Arid Environments, vol. 61, no. 1, pp. 147-160, 2005.
[30] S. Jauffret, Validation et comparaison de divers indicateurs des changements à long terme dans les écosystèmes Méditerranéens arides [Ph.D. thesis], Univ de Droit, d'Économie et des Sciences d' Aix- Marseille, 2001.

[31] P. Waechter, Etude des relations entre les animaux domestiques et la végétation dans les steppes du sud de la Tunisie. Implications pastorales [Ph.D. thesis], University of Science and Techniques of Languedoc, Montpellier, France, 1982.

[32] E. Le Floc'h, Biodiversité et Gestion Pastorale en Zones Arides et Semi-Arides Méditerranéennes du Nord de L’Afrique, vol. 13, Bocconea, 2001.

[33] C. Römermann, T. Dutoit, P. Poschlod, and E. Buisson, "Influence of former cultivation on the unique Mediterranean steppe of France and consequences for conservation management," Biological Conservation, vol. 121, no. 1, pp. 21-33, 2005.

[34] D. Tscherko, U. Hammesfahr, G. Zeltner, E. Kandeler, and R. Böcker, "Plant succession and rhizosphere microbial communities in a recently deglaciated alpine terrain," Basic and Applied Ecology, vol. 6, no. 4, pp. 367-383, 2005. 

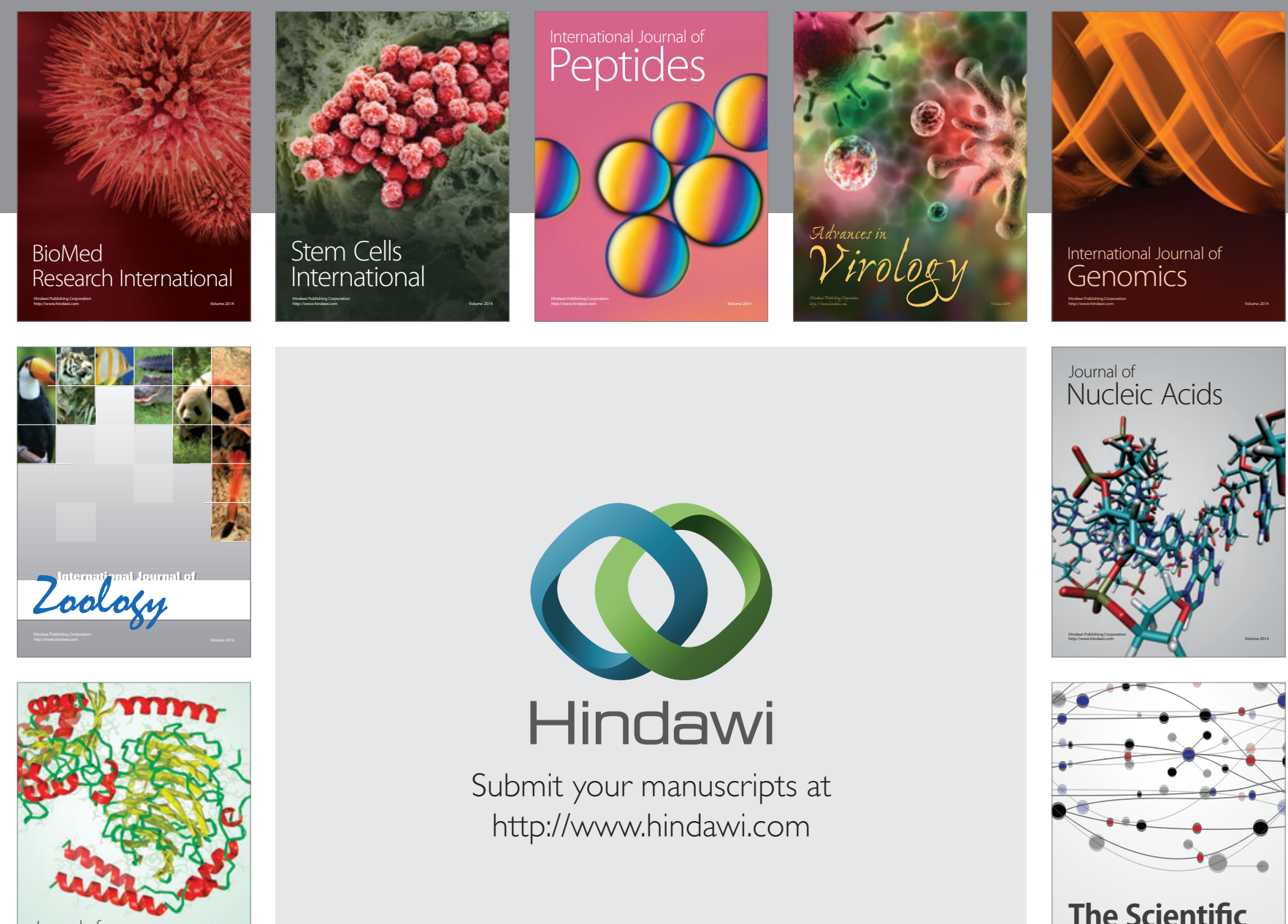

Submit your manuscripts at

http://www.hindawi.com

Journal of
Signal Transduction
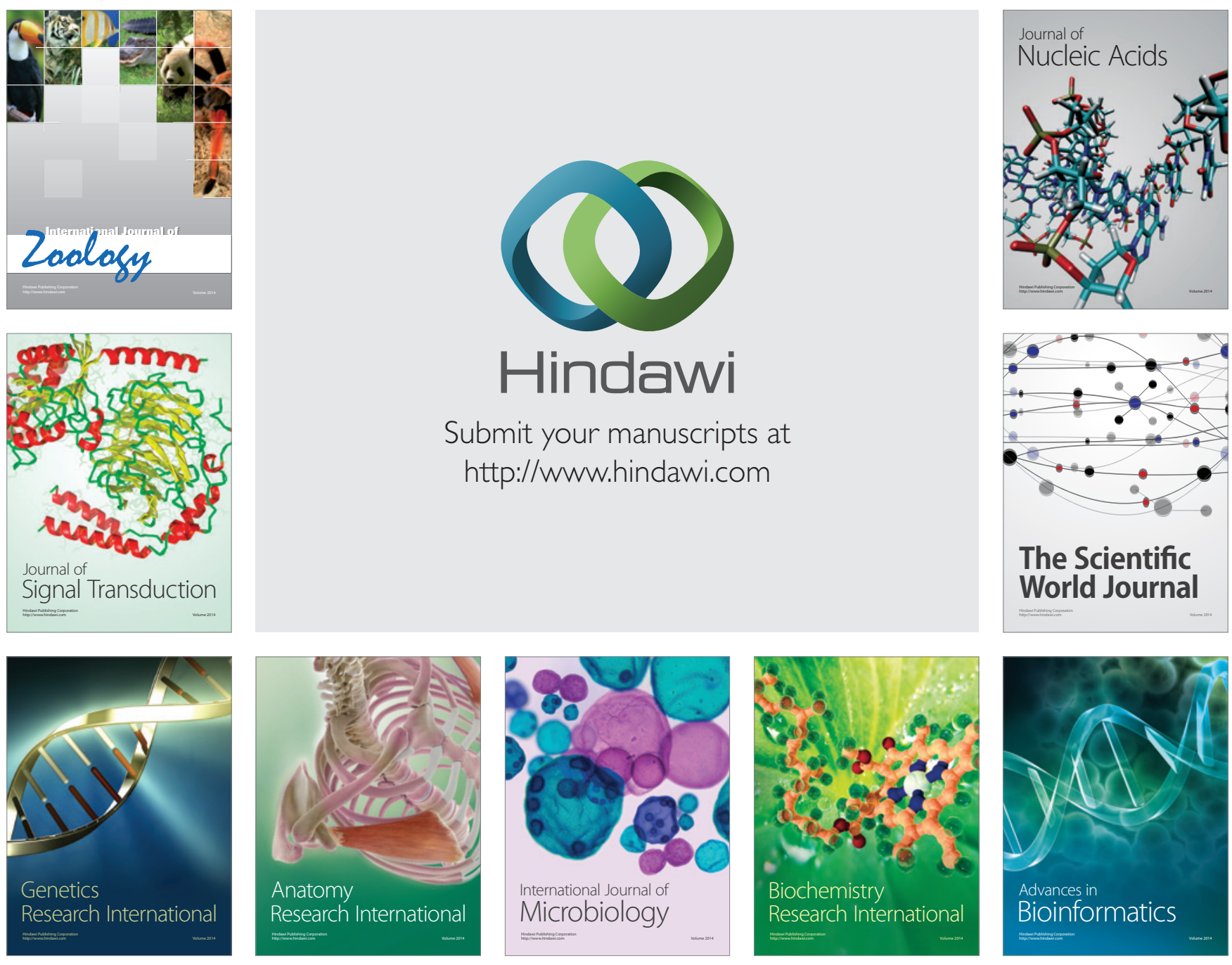

The Scientific World Journal
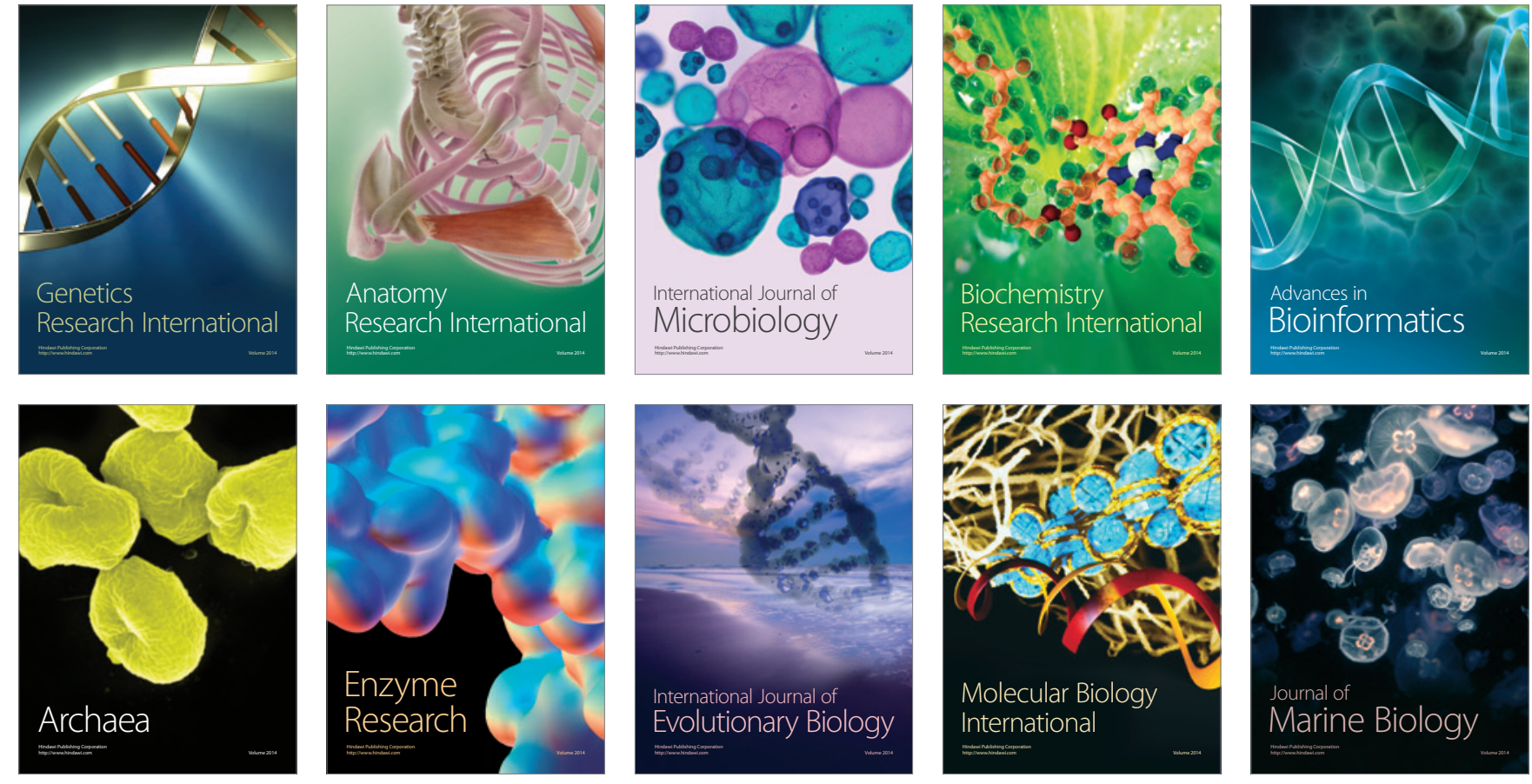